\title{
Phosphoproteomics in Microbiology: Protocols for studying Streptomyces coelicolor differentiation
}

Angel Manteca ${ }^{1}$, Beatriz Rioseras ${ }^{1}$, Adelina Rogowska-Wrzesinska ${ }^{2}$, and Ole N. Jensen $^{2}$

${ }^{1}$ Area de Microbiologia, Departamento de Biologia Funcional and IUOPA, Facultad de Medicina, Universidad de Oviedo, 33006 Oviedo, Spain

2 Department of Biochemistry and Molecular Biology, University of Southern Denmark, Campusvej 55, DK-5230 Odense M, Denmark

Key words: Streptomyces / phosphoproteomics / differentiation / sporulation / LCMS/MS

Correspondence: Dr. Angel Manteca Fernandez, Area de Microbiologia, Departamento de Biologia Funcional and IUOPA, Facultad de Medicina, Universidad de Oviedo, 33006 Oviedo, Spain; Prof. Ole Nørregaard Jensen, Department of Biochemistry and Molecular Biology, University of Southern Denmark, Campusvej 55, DK-5230 Odense M, Denmark

E-mail: mantecaangel@uniovi.es; jenseno@bmb.sdu.dk

Phone: (34) 985103555; Fax: (34) 985103148 


\section{Summary}

The extension and biological role of Ser/Thr/Tyr phosphorylation in prokaryotes has been only scarcely studied. In this chapter, we describe the state of the art of microbial phosphoproteomics, focusing on protocols used for studying the phosphoproteome of Streptomyces coelicolor, one of the bacteria encoding the largest number of eukaryote-like Ser/Thr/Tyr kinases.

\section{Introduction}

Reversible protein phosphorylation at serine, threonine, and tyrosine residues is a well-known dynamic post-translational modification with stunning regulatory and signaling potential in eukaryotes [1]. In contrast, the extension and biological function of Ser/Thr/Tyr protein phosphorylation in bacteria are in most cases only poorly defined. Histidine/aspartate phosphorylations are common in bacterial two-component systems [2,3], but its extension and biological role remains basically unknown. This is a direct consequence of the high instability of histidine phosphorylation in the acidic conditions used in phosphoproteomic protocols [4]. This chapter focus on bacterial Ser/Thr/Tyr phosphorylation.

During the last years, large-scale Ser/Thr/Tyr phosphoproteome studies were reported for E. coli [5,6], Streptococcus pneumonia [7], Klebsiella pneumoniae [8], Lactococcus lactis [9], Pseudomonas [10], Bacillus subtilis [11], Halobacterium salinarum [12], Clostridium acetobutylicum [13], Streptomyces coelicolor [14,15], Mycobacterium tuberculosis [16], Acinetobacter baumanii [17], Listeria monocytogenes [18], Rhodopseudomomas palustris [19], Thermus termophilus [20], 
Helicobacter pylori [21], or Staphylococcus aureus [22] (Table 1). The extent of protein phosphorylation in bacteria is dramatically low in comparison to eukaryotes, making bacterial phosphoproteomics a challenge. Most bacterial phosphoproteomic studies only analyzed the vegetative stages, due to the fact that differentiation is uncharacterized for most bacteria. The only two studies analyzing different developmental stages in bacteria, demonstrated that phosphorylation is dramatically higher at the differentiated stages of S. coelicolor [15] and E. coli [6]. Quantitative phosphoproteomics is challenging, and to our knowledge, there are only two published gel-free quantitative phosphoproteomic studies in bacteria: the label-free quantitative phosphoproteomics performed in S. coelicolor [15], and the stable isotope labeling by amino acids in cell culture (SILAC) performed in E. coli [6]. All published mass spectrometry based bacterial phosphoproteomics studies applied $\mathrm{TiO}_{2}$ for phosphopeptide enrichment, because the low phosphorylation levels of prokaryotes made other methods, such as Immobilized Metal Affinity Chromatography (IMAC), inadequate. Most of the bacterial phosphoproteomic studies used rather large amounts of protein starting material (milligrams) obtained during the vegetative growth state to detect relatively low numbers of phosphopeptides (Table 1).

In this chapter we describe the mass spectrometry based experimental workflow and analytical methods used for studying the Streptomyces coelicolor phosphoproteome [15], which consists of pre-fractionation of peptide samples by means of calcium phosphate precipitation (CPP) of phosphopeptides [23] prior to titanium dioxide $\left(\mathrm{TiO}_{2}\right)$ affinity-enrichment of phosphopeptides. CPP enhances dramatically the number of Ser/Thr/Tyr phosphopeptides identified. 
Streptomycetes produce most of the biologically active compounds used in biomedicine [24-27]. They have complex life cycles (reviewed in [28]), and represent the evolutionary origin of several protein domains that are known to regulate eukaryotic signalling pathways, including eukaryotic-like protein kinases [29]. Streptomyces coelicolor, the model Streptomyces strain [30], encodes 47 predicted eukaryote-like protein kinases, twice the number of kinases predicted from genomes of other well characterized bacteria, including E. coli and Bacillus subtilis (Table 1), and it has been demonstrated to be a good model for the study of bacterial Ser/Thr/Tyr phosphorylation [15].

\section{Materials}

\subsection{Streptomyces strain and developmental conditions}

1. GYM medium [31]: $5 \mathrm{~g} / 1$ glucose, $4 \mathrm{~g} / 1$ yeast extract, $5 \mathrm{~g} / 1$ malt extract, $0.5 \mathrm{~g} / 1$ $\mathrm{MgSO}_{4} .7 \mathrm{H}_{2} \mathrm{O}, 20 \mathrm{~g} / \mathrm{l}$ agar. Before plating, supplement with $0.5 \mathrm{~g} / 1 \mathrm{~K}_{2} \mathrm{HPO}_{4}$ (add $2 \mathrm{ml}$ per liter of a stock solution of $0.25 \mathrm{~g} / \mathrm{ml})$.

2. Cellophane disks: Use cellophane from bookshop. Cut the cellophane into discs of the diameter of a petri plate, before autoclaving.

3. Incubator $\left(30^{\circ} \mathrm{C}\right)$.

\subsection{Protein extraction and sample preparation}

1. Lysis buffer: $2 \%$ SDS, $50 \mathrm{mM}$ Tris- $\mathrm{HCl} \mathrm{pH} 7,150 \mathrm{mM} \mathrm{NaCl}, 10 \mathrm{mM} \mathrm{MgCl}$, 1mM EDTA, 7 mM ß-mercaptoethanol, EDTA-free Protease Inhibitor Cocktail Tablets (e.g. Roche) and 1\% phosphatase inhibitor (e.g. mixtures 1 and 2 from Sigma). 
2. Centrifuge

3. Vacuum centrifuge

4. Acetone, pure

5. Ethanol (EtOH), absolute

6. Washing solution 1: $50 \%$ (v/v) $\mathrm{H}_{2} \mathrm{O}, 25 \%$ (v/v) EtOH, 25\% (v/v) acetone

7. Distilled water

8. 12,000 Da dialysis tubing (e.g. Sigma)

9. Bradford reagent or an alternative method for protein concentration determination

10. Dithiothreitol (DTT): 0.5 M DTT stock solution

11. Ammonia in water $\left(\mathrm{NH}_{3}-\mathrm{H}_{2} \mathrm{O}\right): 2 \mathrm{M} \mathrm{NH}_{3}$ in water

12. Iodoacetamide (IAA): $150 \mathrm{mM}$ IAA stock

13. Trypsin

\subsection{Calcium phosphate precipitation (CPP)}

1. Solution 1: $0.5 \mathrm{M} \mathrm{Na}_{2} \mathrm{HPO}_{4}$

2. Solution 2: $2 \mathrm{M} \mathrm{NH}_{3} \cdot \mathrm{H}_{2} \mathrm{O}$

3. Solution 3: $2 \mathrm{M} \mathrm{CaCl}_{2}$

4. Washing solution 2: $80 \mathrm{mM} \mathrm{CaCl} 2$

5. Formic acid: $5 \%(\mathrm{v} / \mathrm{v})$ formic acid 
6. Acetonitrile (ACN): $50 \%(\mathrm{v} / \mathrm{v}) \mathrm{ACN}$

7. POROS® R3 (Applied Biosystems) reversed-phase media.

\subsection{Enrichment of phosphopeptides using $\mathrm{TiO}_{2}$ and desalting}

1. $\mathrm{C} 8$ disks (3M $\mathrm{M}^{\mathrm{TM}}$ Empore ${ }^{\mathrm{TM}}$ High Performance Extraction Disk).

2. $\mathrm{ACN}$

3. $\mathrm{TiO}_{2}$ : Titansphere, $5 \mu \mathrm{m}$ (e.g. GL Sciences).

4. Loading solution: $1 \mathrm{M}$ glycolic acid, $5 \%(\mathrm{v} / \mathrm{v})$ trifluoroacetic acid (TFA) (sequencing grade), 80\% (v/v) ACN (HPLC grade).

5. Washing solution 3: 80\% 8(v/v) ACN (HPLC grade), 1\% (v/v) TFA (sequencing grade).

6. Ammonia in water $\left(\mathrm{NH}_{3}-\mathrm{H}_{2} \mathrm{O}\right): 2 \mathrm{M} \mathrm{NH}_{3}$ in water

7. Elution solution 1: $40 \%$ (v/v) $\mathrm{ACN} / 1 \mathrm{M} \mathrm{NH}_{3}-\mathrm{H}_{2} \mathrm{O}$

8. Formic acid: $3.5 \%(\mathrm{v} / \mathrm{v})$ formic acid

9. POROS® R3 (Applied Biosystems) reversed-phase media.

10. Equilibration solution: $0.5 \%(\mathrm{v} / \mathrm{v})$ formic acid

11. Elution solution 2: $50 \%(\mathrm{v} / \mathrm{v}) \mathrm{ACN}, 0.5 \%(\mathrm{v} / \mathrm{v})$ formic acid

12. Elution solution 3: 70\% (v/v) ACN, $0.5 \%(\mathrm{v} / \mathrm{v})$ formic acid

\subsection{LC-MS/MS analysis}


1. LC-ESI-MS/MS system: For example, a nano EasyLC system (Thermo Fisher Scientific, Odense, Denmark) interfaced by an ESI source to a LTQ-Orbitrap XL or an Q-Exactive tandem mass spectrometer (Thermo Fisher Scientific, Bremen, Germany).

2. Formic acid: $0.5 \%(\mathrm{v} / \mathrm{v})$ formic acid

3. Fused silica column: in-house packed fused silica column, $16 \mathrm{~cm}$ length, $100 \mu \mathrm{m}$ inner diameter, $375 \mu \mathrm{m}$ outer diameter, filled with ReproSil, C18 AQ $3 \mu \mathrm{m}$; (e.g. Dr. Maisch, Ammerbuch, Germany)

4. HPLC solvent A: $0.1 \%(\mathrm{v} / \mathrm{v})$ formic acid

5. HPLC solvent B: $90 \%(\mathrm{v} / \mathrm{v})$ ACN, $0.1 \%(\mathrm{v} / \mathrm{v})$ formic acid

6. ProteomeDiscoverer Software version 1.2 (Thermo Scientific)

7. Mascot server version 2.3.02 (Matrix Science)

\section{Methods}

Experimental workflow is detailed in the next paragraphs and outlined in Figure 1.

\subsection{Streptomyces strain and developmental conditions}

Use the model Streptomyces coelicolor M145 strain [30], or another Streptomyces whose genome is sequenced. Streptomyces coelicolor developmental cycle and culture conditions are well known [28]. As introduced above, one of the keys to increase the number of detected phosphorylation sites in Streptomyces is to analyse 
different developmental stages: vegetative, MI; and reproductive, MII/sporulation [15]. In the case of $S$. coelicolor, solid sporulating cultures can be prepared as described by Manteca et al. [15]: inoculate plates of GYM medium, covered with cellophane disks, with $100 \mu \mathrm{l}$ of a spore suspension $\left(1 \times 10^{7}\right.$ viable spores $\left./ \mathrm{ml}\right)$; incubate them at $30^{\circ} \mathrm{C}$; analyse three key developmental stages (12h, MI; 24h, MII; and 72h, sporulating MII).

\subsection{Protein extraction and sample preparation}

1. Collect the mycelial lawns of S. coelicolor M145 (or alternative species) growing on cellophane disks at different time points $(12,24$, and 72 hours) using a plain spatula. Process as many biological replicates as possible, ideally, those necessary to ensure rigorous statistical analysis. Multiple replicates adds to the workload, specially MS instrumentation time, and may not always be feasible. Process at least two biological replicates for each developmental stage.

2. Lyse the cells boiling the samples in lysis buffer (10 minutes). Use $65 \mathrm{mg}$ of fresh weight mycelium per ml of lysis buffer (see Note 1).

3. Centrifuge at $20,000 \mathrm{x}$ g for 10 minutes.

4. Collect the supernatant.

5. Reduce sample viscosity by sonication (4 cycles of 10 seconds, on ice).

6. Precipitate the protein with acetone/ethanol (1volume sample / 4 volumes ethanol / 4 volumes acetone). Store over night at $-20{ }^{\circ} \mathrm{C}$ (see Note 2).

7. Centrifuge at $20,000 \mathrm{gs}$ for 10 minutes at $4^{\circ} \mathrm{C}$.

8. Discard the supernatant. 
9. Wash the pellet with precooled $\left(-20^{\circ} \mathrm{C}\right)$ washing solution 1 .

10. Repeat steps 7 and 8.

11. Resuspend the pellet in precooled $\left(4^{\circ} \mathrm{C}\right)$ distillated water.

12. Dialyze the sample against large volumes of water $\left(1\right.$ hour at $4{ }^{\circ} \mathrm{C}$, change water every 15 minutes) (see Note 3 ).

13. Determine protein concentration (e.g. Bradford method [28] or any other alternative')

14. Lyophilize samples in aliquots (for instance $100 \mu \mathrm{g}$ of protein per aliquot).

15. Store the lyophilized samples at $-80{ }^{\circ} \mathrm{C}$ (see Note 4).

\subsection{In solution trypsin digestion.}

1. Resuspend the protein in distilled water (add $25 \mu$ l of water to $50 \mu \mathrm{g}$ of protein) (see Note 5).

2. Add DTT to a final concentration of $5 \mathrm{mM}(0.25 \mu \mathrm{l}$ of the $0.5 \mathrm{M}$ DTT stock to 25 $\mu 1$ ). Adjust the $\mathrm{pH}$ to 8 with $2 \mathrm{M} \mathrm{NH}_{3}-\mathrm{H}_{2} \mathrm{O}$ (see Note 5).

3. Incubate at $37^{\circ} \mathrm{C}$ for 45 minutes.

4. Take out the sample from $37^{\circ} \mathrm{C}$, leave it at room temperature until it cool down.

5. Add IAA to a final concentration of $15 \mathrm{mM}(2.5 \mu \mathrm{l}$ of the $150 \mathrm{mM}$ IAA stock), check the $\mathrm{pH}$ (see Note 6).

6. Incubate at room temperature for 45 minutes, in the dark.

7. Add the same amount of DTT as in step 2. 
8. Add trypsin $(0.5 \mu \mathrm{g}$ of trypsin to the $25 \mu \mathrm{g}$ of protein $)$.

9. Incubate at $37^{\circ} \mathrm{C}$ over night.

\subsection{Phosphopeptide enrichment - CPP pre-fractionation/ $\mathrm{TiO}_{2}$.}

1. Adjust the volume of the peptide solution $(50 \mu \mathrm{g})$ to $100 \mu \mathrm{l}$ with distilled water.

2. Adjust the $\mathrm{pH}$ of the sample solution to $9-10$ using $2 \mathrm{M} \mathrm{NH}_{3}-\mathrm{H}_{2} \mathrm{O}$ (see Note 6).

3. Add $8 \mu \mathrm{l}$ of precipitation solutions 1 and $8 \mu \mathrm{l}$ of precipitation solutions 2 to the $100 \mu \mathrm{l}$ sample solution and mix.

4. Add $8 \mu$ l of precipitation solution 3 and vortex.

5. Centrifuge at $20,000 \times \mathrm{g}$ for 10 minutes at room temperature.

6. Discard the supernatant (this supernatant contains the non-phosphorylated peptides and can be stored to compare it with the phosphopeptide-enriched sample).

7. Add $120 \mu \mathrm{l}$ of washing solution 2 to the pellet, vortex until it is suspended.

8. Centrifuge at $20,000 \mathrm{x} \mathrm{g}$ for 5 minutes.

9. Repeat steps $6-8$.

10. Discard the supernatant.

11. Dissolve the pellet with $40 \mu 1$ of $5 \%$ (v/v) formic acid.

12. Desalt the resulting solution by reverse phase chromatography as detailed below (section 3.5); store the dried phosphopeptides at $-20^{\circ} \mathrm{C}$ (see Notes 4 and 7). 
13. Prepare $\mathrm{TiO}_{2}$ microcolumns putting a plug of the $\mathrm{C} 8$ disk into the narrow end of the tip and load the $\mathrm{TiO}_{2}$ material on top (see Note 8).

14. Wash the column with $30 \mu \mathrm{l}$ of $100 \% \mathrm{ACN}$.

15. Resuspend the dried CPP pre-enriched sample (step 12) in $25 \mu 1$ of loading solution.

16. Load the sample on the $\mathrm{TiO}_{2}$ microcolumn.

17. Collect the flow through and load it a second time on the same column.

18. Wash with $25 \mu 1$ of loading solution.

19. Wash with $25 \mu 1$ of washing solution 3 (two times).

20. Elute the peptides with $10 \mu \mathrm{l}$ of $2 \mathrm{M} \mathrm{NH}_{3}-\mathrm{H}_{2} \mathrm{O}$ (two times).

21. Elute with $2 \mu$ l elution solution 1 to elute the phosphopeptides that bind to the C8-disk.

22. Vacuum dry the sample, resuspend it in $30 \mu 13.5 \%$ (v/v) formic acid (FA), and desalt it using the protocol detailed below (section 3.5).

\subsection{Sample desalting}

1. Prepare an oligoR3 RP column into a p200 pipette tip with C18 plug. Equilibrate the column with $50 \mu$ l equilibration solution. (see Note 9).

2. Load the acidified peptide mixture onto the column.

3. Wash the column with $50 \mu$ l equilibration solution 
4. Elute peptides in a two-step elution of peptides with $30 \mu 1$ elution solution 2 and $20 \mu$ elution solution 3 .

5. Combine the eluates and dry down in a vacuum centrifuge. Store at $-20{ }^{\circ} \mathrm{C}$ until further analysis (see Note 7).

\subsection{LC-MS/MS analysis}

1. For LC-MSMS analysis resuspend samples in $0.5 \%(\mathrm{v} / \mathrm{v})$ formic acid.

2. Analyse samples using nanoliter flow chromatography (nanoLC) interfaced to a high mass resolution electrospray tandem mass spectrometer (LC-ESI-MS/MS). For example a nanoliter flow EasyLC system (Thermo Fisher Scientific, Odense, Denmark) coupled to a Q-Exactive ESI tandem mass spectrometer (Thermo Fisher Scientific, Bremen, Germany) can be used. (see Note 10).

3. Separate peptides using an in-house packed fused silica

4. Inject $5 \mu$ of peptide/phosphopeptide sample onto the column.

5. Separate peptides using a linear 50 min gradient from $0 \%$ to $34 \%$ of solvent $\mathrm{B}$ with a constant flow of $250 \mathrm{nl} / \mathrm{min}$.

6. Record mass spectra in in the positive ion mode with data dependent acquisition. Acquire survey scans in the $\mathrm{m} / \mathrm{z}$ range $400-2000$ in the Orbitrap at a mass resolution of 60000 FWHM. Perform collision induced dissociation MS/MS of 5-10 most intense ions in the linear ion trap with an activation time of $15 \mathrm{~s}$.

7. Convert raw data into peak lists using for example Proteome Discoverer software. Generate mgf files, perform database searches using for example Mascot server (version 2.3.02; Matrix Science), search against the NCBInr 
database. Use the following parameters to filter the results: precursor mass tolerance $10 \mathrm{ppm}$, fragment ion mass tolerance of $0.8 \mathrm{Da}$, fixed modifications: carbamidomethylation of Cys residues; variable modifications: phosphorylation of Ser/Thr/Tyr, oxidation of Met; enzyme: trypsin, two missed cleavages allowed (see Note 11).

\subsection{Criteria to validate candidate phosphopeptides}

Candidate phosphopeptides are validated by manual inspection of their respective MS/MS spectra using the next criteria (see Manteca et al. [15] for examples). Peptides should have:

1. At least 4 consecutive $y$ or $b$ ions.

2. An intense signal should be assigned to ions produced by fragmentation at peptide bond $\mathrm{N}$-terminal to proline if proline is present in the sequence.

3. Phosphoserine sites were assigned by the appearance of a 69Da (dehydroSer) and 167Da (phosphoserine, 87+80 Da) distance between fragment ions.

4. Phosphothreonine sites were assigned by the appearance of 83Da (dehydroThr) and 181Da (phosphothreonine, $80+101 \mathrm{Da}$ ) distance for phosphothreonine.

5. Phosphotyrosine containing peptides were validated by the observation of a mass increase of $80 \mathrm{Da}$ to unmodified peptide and the presence of the immonium ion at $\mathrm{m} / \mathrm{z} 216$ (singly charged) or a mass difference of 243Da between fragment ions in spectra. 


\subsection{Label free quantitative analysis}

The relative abundance of the phosphopeptides at different developmental stages is estimated based in the averaged counts per second following the next criteria (see Manteca et al. [15] for examples):

1. Phosphopeptides were only considered for quantification if they were detected and sequenced in two biological replicates.

2. Average abundance was calculated in the 24 LC-MS/MS runs.

3. For the LC-MS/MS runs in which the precursor ion was not sequenced, it was searched manually using a tolerance of 0.14 min for retention time and $5 \mathrm{ppm}$ as mass tolerance.

4. Relative abundances were considered as significant when the average counts per second +/- SD were not overlapping between developmental stages.

\section{Notes}

1. Collect the sample in lysis buffer in ice. Boil the samples in the SDS-lysis buffer as soon as possible to inactive phosphatases/proteases and to stabilize the phosphoproteome.

2. Ethanol/acetone precipitation is critical to remove SDS.

3. Dialysis cleans rests of SDS and salts, but it is not critical.

4. In order to minimize methodological variation, prepare single use aliquots, process them as soon as possible, and use samples with the same storage times. 
5. Do not use a buffer during trypsin digestion, because it interferes with CPP. The stock of IAA (150 mM) should be prepared freshly for each digestion. Prepare it in water, and adjust the $\mathrm{pH}$ to 8 with $2 \mathrm{M} \mathrm{NH}_{3}-\mathrm{H}_{2} \mathrm{O}$ (see also Note 1).

6. Adjust the $\mathrm{pH}$ to $9-10$ is critical for $\mathrm{CPP} . \mathrm{pH}$ should be checked adding minimal volumes (around $0.2 \mu \mathrm{l}$ ) to $\mathrm{pH}$ strips.

7. Take into account that CPP is a phosphopeptide pre-enrichment, and most peptides in the CPP pre-enriched sample are not phosphorylated

8. In order to improve reproducibility of the label free quantification between replicates, $\mathrm{TiO}_{2}$ microcolumns should be as homogeneous as possible.

9. OligoR3 RP microcolumn should be big enough to retain all the peptides. This can be checked analyzing the absence of peptides in the column flow through by MALDI-TOF.

10. It is recommended to perform 2 to 5 replicate analysis.

11. Take into account that most of the peptides identified in the final $\mathrm{CPP}-\mathrm{TiO}_{2}$ enriched sample are not phosphorylated due to the low level of Ser/Thr/Tyr phosphorylation in bacteria.

\section{Acknowledgments}

We wish to thank the European Research Council (ERC Starting Grant; Strpdifferentiation 280304), the Spanish 'Ministerio de Economı'a y Competitividad' (MINECO; BIO2015-65709-R) and the VILLUM Foundation (VILLUM Center for Bioanalytical Sciences at University of Southern Denmark) for financial support. 


\section{References}

1. Pawson T, Scott JD (2005) Protein phosphorylation in signaling--50 years and counting. Trends Biochem Sci 30 (6):286-290

2. Hoch JA (2000) Two-component and phosphorelay signal transduction. Curr Opin Microbiol 3 (2): $165-170$

3. Galperin MY, Nikolskaya AN, Koonin EV (2001) Novel domains of the prokaryotic twocomponent signal transduction systems. FEMS Microbiol Lett 203 (1):11-21

4. Kleinnijenhuis AJ, Kjeldsen F, Kallipolitis B, Haselmann KF, Jensen ON (2007) Analysis of histidine phosphorylation using tandem MS and ion-electron reactions. Anal Chem 79 (19):7450-7456

5. Macek B, Gnad F, Soufi B, Kumar C, Olsen JV, Mijakovic I, Mann M (2008) Phosphoproteome analysis of E. coli reveals evolutionary conservation of bacterial Ser/Thr/Tyr phosphorylation. Mol Cell Proteomics 7 (2):299-307

6. Soares NC, Spat P, Krug K, Macek B (2013) Global dynamics of the Escherichia coli proteome and phosphoproteome during growth in minimal medium. J Proteome Res 12 (6):2611-2621

7. Sun X, Ge F, Xiao CL, Yin XF, Ge R, Zhang LH, He QY (2010) Phosphoproteomic analysis reveals the multiple roles of phosphorylation in pathogenic bacterium Streptococcus pneumoniae. J Proteome Res 9 (1):275-282

8. Lin MH, Hsu TL, Lin SY, Pan YJ, Jan JT, Wang JT, Khoo KH, Wu SH (2009) Phosphoproteomics of Klebsiella pneumoniae NTUH-K2044 reveals a tight link between tyrosine phosphorylation and virulence. Mol Cell Proteomics 8 (12):2613-2623

9. Soufi B, Gnad F, Jensen PR, Petranovic D, Mann M, Mijakovic I, Macek B (2008) The Ser/Thr/Tyr phosphoproteome of Lactococcus lactis IL1403 reveals multiply phosphorylated proteins. Proteomics 8 (17):3486-3493

10. Ravichandran A, Sugiyama N, Tomita M, Swarup S, Ishihama Y (2009) Ser/Thr/Tyr phosphoproteome analysis of pathogenic and non-pathogenic Pseudomonas species. Proteomics 9 (10):2764-2775

11. Macek B, Mijakovic I, Olsen JV, Gnad F, Kumar C, Jensen PR, Mann M (2007) The serine/threonine/tyrosine phosphoproteome of the model bacterium Bacillus subtilis. Mol Cell Proteomics 6 (4):697-707

12. Aivaliotis M, Macek B, Gnad F, Reichelt P, Mann M, Oesterhelt D (2009) Ser/Thr/Tyr protein phosphorylation in the archaeon Halobacterium salinarum--a representative of the third domain of life. PLoS One 4 (3):e4777

13. Bai X, Ji Z (2012) Phosphoproteomic investigation of a solvent producing bacterium Clostridium acetobutylicum. Appl Microbiol Biotechnol 95 (1):201-211

14. Parker JL, Jones AM, Serazetdinova L, Saalbach G, Bibb MJ, Naldrett MJ (2010) Analysis of the phosphoproteome of the multicellular bacterium Streptomyces coelicolor A3(2) by protein/peptide fractionation, phosphopeptide enrichment and high-accuracy mass spectrometry. Proteomics 10 (13):2486-2497

15. Manteca A, Ye J, Sanchez J, Jensen ON (2011) Phosphoproteome analysis of Streptomyces development reveals extensive protein phosphorylation accompanying bacterial differentiation. J Proteome Res 10 (12):5481-5492

16. Prisic S, Dankwa S, Schwartz D, Chou MF, Locasale JW, Kang CM, Bemis G, Church GM, Steen H, Husson RN (2010) Extensive phosphorylation with overlapping specificity by 
Mycobacterium tuberculosis serine/threonine protein kinases. Proc Natl Acad Sci U S A 107 (16):7521-7526

17. Soares NC, Spat P, Mendez JA, Nakedi K, Aranda J, Bou G (2014) Ser/Thr/Tyr phosphoproteome characterization of Acinetobacter baumannii: comparison between a reference strain and a highly invasive multidrug-resistant clinical isolate. J Proteomics 102:113124

18. Misra SK, Milohanic E, Ake F, Mijakovic I, Deutscher J, Monnet V, Henry C (2011) Analysis of the serine/threonine/tyrosine phosphoproteome of the pathogenic bacterium Listeria monocytogenes reveals phosphorylated proteins related to virulence. Proteomics 11 (21):41554165

19. Hu CW, Lin MH, Huang HC, Ku WC, Yi TH, Tsai CF, Chen YJ, Sugiyama N, Ishihama Y, Juan HF, Wu SH (2012) Phosphoproteomic analysis of Rhodopseudomonas palustris reveals the role of pyruvate phosphate dikinase phosphorylation in lipid production. J Proteome Res 11 (11):5362-5375

20. Takahata Y, Inoue M, Kim K, Iio Y, Miyamoto M, Masui R, Ishihama Y, Kuramitsu S (2012) Close proximity of phosphorylation sites to ligand in the phosphoproteome of the extreme thermophile Thermus thermophilus HB8. Proteomics 12 (9):1414-1430

21. Ge R, Sun X, Xiao C, Yin X, Shan W, Chen Z, He QY (2011) Phosphoproteome analysis of the pathogenic bacterium Helicobacter pylori reveals over-representation of tyrosine phosphorylation and multiply phosphorylated proteins. Proteomics 11 (8):1449-1461

22. Bäsell K, Otto A, Junker S, Zühlke D, Rappen GM, Schmidt S, Hentschker C, Macek B, Ohlsen K, Hecker M, Becher D (2014) The phosphoproteome and its physiological dynamics in Staphylococcus aureus. Int J Med Microbiol. 304 (2):121-32

23. Zhang X, Ye J, Jensen ON, Roepstorff P (2007) Highly Efficient Phosphopeptide Enrichment by Calcium Phosphate Precipitation Combined with Subsequent IMAC Enrichment. Mol Cell Proteomics 6 (11):2032-2042

24. Omura S (1992) The expanded horizon for microbial metabolites--a review. Gene 115 (12):141-149

25. Tamaoki T, Nakano H (1990) Potent and specific inhibitors of protein kinase $\mathrm{C}$ of microbial origin. Biotechnology (N Y) 8 (8):732-735

26. Umezawa K (1997) Induction of cellular differentiation and apoptosis by signal transduction inhibitors. Adv Enzyme Regul 37:393-401

27. Katz L, Baltz RH (2016) Natural product discovery: past, present, and future. J Ind Microbiol Biotechnol 43:155-176.

28. Yague P, Lopez-Garcia MT, Rioseras B, Sanchez J, Manteca A (2013) Pre-sporulation stages of Streptomyces differentiation: state-of-the-art and future perspectives. FEMS Microbiol Lett 342 (2):79-88

29. Perez J, Castaneda-Garcia A, Jenke-Kodama H, Muller R, Munoz-Dorado J (2008) Eukaryotic-like protein kinases in the prokaryotes and the myxobacterial kinome. Proc Natl Acad Sci U S A 105 (41):15950-15955

30. Bentley SD, Chater KF, Cerdeno-Tarraga AM, Challis GL, Thomson NR, James KD, Harris DE, Quail MA, Kieser H, Harper D, Bateman A, Brown S, Chandra G, Chen CW, Collins M, Cronin A, Fraser A, Goble A, Hidalgo J, Hornsby T, Howarth S, Huang CH, Kieser T, Larke L, Murphy L, Oliver K, O'Neil S, Rabbinowitsch E, Rajandream MA, Rutherford K, Rutter S, Seeger K, Saunders D, Sharp S, Squares R, Squares S, Taylor K, Warren T, Wietzorrek A, Woodward J, Barrell BG, Parkhill J, Hopwood DA (2002) Complete genome sequence of the model actinomycete Streptomyces coelicolor A3(2). Nature 417 (6885):141-147 
31. Novella IS, Barbes C, Sanchez J (1992) Sporulation of Streptomyces antibioticus ETHZ 7451 in submerged culture. Can J Microbiol 38 (8):769-773

32. Sharma K, D'Souza RC, Tyanova S, Schaab C, Wisniewski JR, Cox J, Mann M (2014) Ultradeep human phosphoproteome reveals a distinct regulatory nature of Tyr and Ser/Thrbased signaling. Cell Rep 8 (5):1583-1594

Table 1: Comparison of $S$. coelicolor phosphoproteome with other published prokaryotic and eukaryotic phosphoproteomes.

The amount of protein used for the phosphoproteomic experiments, the number of genome ORFs, and number of phosphoproteins/phosphopeptides/phosphosites are shown. n.r. not reported.

\begin{tabular}{|c|c|c|c|c|c|c|}
\hline & Bacterium & $\begin{array}{c}\text { Protein } \\
(\mathrm{mg})^{1}\end{array}$ & Phosphoproteins & Phosphopeptides & $\begin{array}{c}\text { Phosphorylation } \\
\text { sites }\end{array}$ & Reference \\
\hline \multirow{9}{*}{ Gram + } & S. coelicolor & 0.3 & 127 & 260 & $289^{2}$ & $\begin{array}{c}\text { Manteca et al. (2011) } \\
\text { [15] }\end{array}$ \\
\hline & S. coelicolor & 50 & 40 & 44 & 46 & $\begin{array}{c}\text { Parker et al. (2010) } \\
{[14]}\end{array}$ \\
\hline & B. subtilis & 10 & 78 & 103 & 78 & $\begin{array}{c}\text { Macek et al. (2007) } \\
\text { [11] }\end{array}$ \\
\hline & $\begin{array}{l}\text { C. } \\
\text { acetobutylicum }\end{array}$ & 2 & 61 & 82 & 107 & Bai et al. (2012) [13] \\
\hline & L. lactis & 20 & 63 & 102 & 79 & Soufi et al. (2008) [9] \\
\hline & M. tuberculosis & n.r. & 301 & 380 & 500 & $\begin{array}{c}\text { Pisic et al. (2010) } \\
\text { [16] }\end{array}$ \\
\hline & S. pneumoniae & 1 & 84 & 102 & 163 & Sun et al. (2010) [7] \\
\hline & $\begin{array}{l}L . \\
\text { monocytogenes }\end{array}$ & 10 & 112 & 155 & 143 & $\begin{array}{c}\text { Misra et al. (2011) } \\
{[18]}\end{array}$ \\
\hline & S. aureus & 50 & 108 & n.r. & 76 & $\begin{array}{l}\text { Bäsell et al. (2014) } \\
\text { [22] }\end{array}$ \\
\hline \multirow{8}{*}{ Gram - } & E. coli & 20 & 79 & 105 & 81 & $\begin{array}{c}\text { Macek et al. (2008) } \\
{[5]}\end{array}$ \\
\hline & K. pneumoniae & 30 & 81 & 117 & 93 & Lin et al. (2009) [8] \\
\hline & P. aeruginosa & 1.2 & 39 & 57 & 61 & $\begin{array}{l}\text { Ravichandran et al. } \\
\text { (2009) [10] }\end{array}$ \\
\hline & P. putida & 1.2 & 59 & 56 & 55 & $\begin{array}{l}\text { Ravichandran et al. } \\
\text { (2009) [10] }\end{array}$ \\
\hline & H. pylori & & 67 & 82 & 126 & Ge et al. (2011) [21] \\
\hline & $\begin{array}{l}\text { R. palustris } \\
(\mathrm{Ch})\end{array}$ & 2 & 54 & 100 & 63 & Hu et al. (2012) [19] \\
\hline & $\begin{array}{l}\text { R. palustris } \\
(P h)\end{array}$ & 2 & 42 & 74 & 59 & Hu et al. (2012) [19] \\
\hline & T. thermophilus & 100 & 48 & 52 & 46 & Takahata et al. (2012) \\
\hline
\end{tabular}




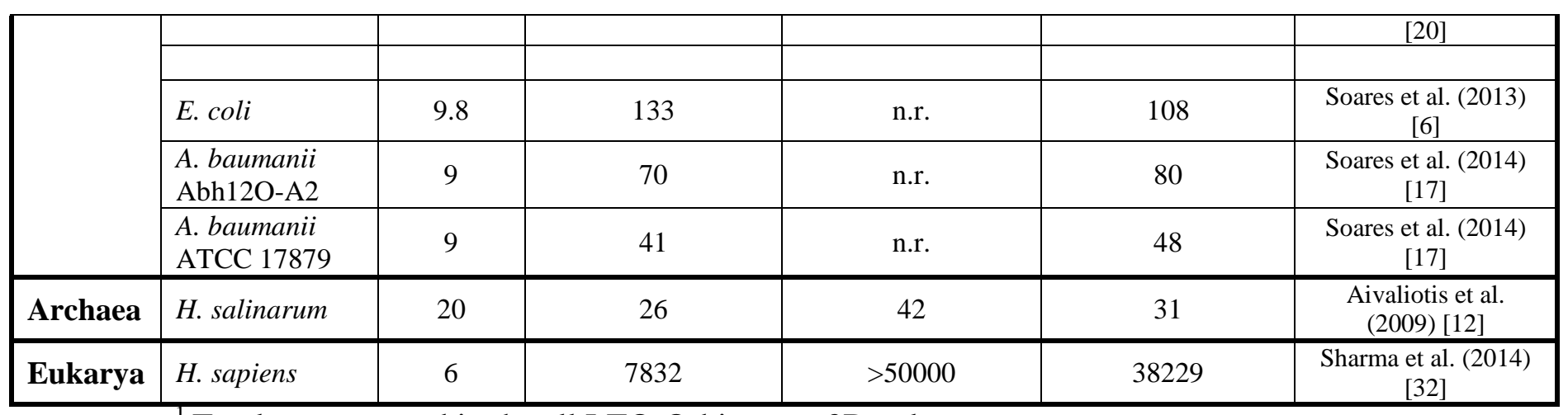

${ }^{1}$ Total amount used in the all LTQ-Orbitrap or 2D gel runs

${ }^{2}$ This is one example out of numerous human phosphoproteome studies. 


\section{FIGURE LEGENDS}

Fig. 1. Overview of the $S$. coelicolor phosphoproteomics workflow. Mycelium from three developmental stages is lysed by boiling in SDS and sonication; proteins are precipitated with acetone-ethanol; trypsin digestion is followed by phosphoenrichment using $\mathrm{CPP}-\mathrm{TiO}_{2}$. Phosphopeptides are separated on nano-HPLC, mass-measured (MS) and fragmented (MS/MS) in the high performance LTQ-Orbitrap mass spectrometer. 